\author{
Oleg V. Chabanuk
}

\title{
FEATURES OF THE RUSSIAN ECONOMY IN THE POST-CRISIS PERIOD
}

PhD in Economics, Associate Professor, Professor of RMAT, Head of Department of Tourism and Hospitality, Deputy Director for Scientific and Methodical Work, Department of Economics and Management, Voskresensk Institute for Tourism -

The Branch of the Russian International Academy for Tourism. Russian International Academy for Tourism, Voskresensk

Institute for Tourism.9g Sovetskaya St., Voskresensk, Moscow Region, 140200, Russia.Chabanuk_oleg@mail.ru

\begin{abstract}
The article studies the stages of development of the modern Russian economy. It analyzes the processes of recovery of the Russian economy after the two crises of 1998 and 2008.

Keywords: innovative development; the stage; the crisis; the growth; the Russian economy.

ОСОБЕННОСТИ ЭКОНОМИКИ РОССИИ В ПОСТКРИЗИСНЫЙ ПЕРИОД
\end{abstract}

Чабанюк О.В.

канд. экон. наук, доцент, профессор кафедры экономики и управления, зав. кафедрой туризма и гостеприимства, зам. директора по научно-методической работе Воскресенского института туризма - филиала Российской международной академии туризма. Российская международная академия туризма, Воскресенский институт туризма ул. Советская, 9г, г. Воскресенск, Московская обл., 140200, Россия. Chabanuk_oleg@mail.ru

\section{Аннотация \\ В статье обоснованы стадии развития современной российской экономики. Проанализированы процессы восстановления российской экономики после 2-х кризисов 1998 и 2008 годов.}

Ключевые слова: инновационное развитие; стадия; кризис; рост; российская экономика.

In modern conditions, the Russian economy is experiencing a major transformation, transitioning to innovative development. Therefore, one of the main questions that should be answered to scientists and economists is - what model of innovative development of the economic system to choose.

In the post-war history of the Russian economy, we can distinguish five stages [6].

In this article, we will focus on the latter two, the most relevant in the light of the transition of the Russian economy to innovative development.

The fourth stage. Accounts for 1998-2007. This stage can be characterized by fairly rapid extensive growth, triggered by the devaluation of the ruble in 1998, and reasonable macroeconomic policies. The generalized indicator of material well-being of Russia surpassed the world average in 2005 (respectively 7.9 and 6.1 thousand per year) and entered into an advanced group of moderately developed countries, but in 3-4 times lower than the leaders.

Foreign direct investment in 2007 reached \$ 47 billion, and it accounting for $3.78 \%$ of GDP. Investments in fixed assets in 2000-2007 increased from 41 to 249 billion dollars. By 2008, Russia has become middle-income countries again, as it was in the twentieth century. This growth has been achieved not only by increasing the production of oil and gas, an engine of growth was the construction (in 2007 an increase of $16 \%)$, trade (12\%), manufacturing $(8 \%)$, and the appreciation of the ruble and prices. These statistics confirm the rapid growth of car ownership, modern appliances, internet users.

According to interviews of independent experts from Levada Center between 1998 and 2007, the number of respondents experiencing confusion and fear of the future declined from 24 to $5 \%$, fatigue and apathy - from 45 to $25 \%$, having hope - has grown from 13 to $41 \%$, over $56 \%$ of respondents believe in the best in 2008. From 2000 to 2007 estimating the number of market-oriented reforms as harmful decreased from 76 to $15 \%$, and as useful - has grown from 14 to $43 \%$. Three times as many respondents felt that they had personally benefited from the reforms.

However, the economic growth was mainly due to extensive and external factors - the reactivation of idle production capacity, which are physically and morally outdated, use, set up in the Soviet era 
infrastructure and technical developments. Assessment Primakov, 2/3 of GDP growth in 2007 was achieved by internal factors - the growth of construction, trade and manufacturing industries. However, calculations of the Institute for the Economy in Transition indicate that external market factor - an increase in prices for oil and natural gas could provide an annual GDP growth of $12-14 \%$ (in fact, in 2007 it was $8.1 \%$ ). According to the Finance Ministry's oil and gas exports to bark more than 52\% of government revenue, including the Stabilization Fund, and the consolidated budget was 37\% of GDP. The rise in prices of exported raw materials during the rapid growth of the world economy to cope with the possible collapse of the 1990s., Has created an essential, but not sufficient conditions for the transition from the inertia of the commodity to the innovative development of fragmented - a comprehensive modernization of the economy.

The fifth stage. Began in 2008. In 2008-2020 is planned to increase labor productivity in 4 times, and on this basis to qualitatively change the economy and the social sphere, to stabilize the population by reducing the mortality rate (1.5-fold) and an increase in life expectancy. This stage is strategically divided into three stages, the passage of which should lead to the achievement of research and innovation policies [5, p. 185].

The first stage of the Russian economy is currently (2008-2012). During this time, it was planned to justify the innovation strategy and priorities for the development of science, create the NIS, to create a legal and regulatory mechanisms for the development of innovative economy. During this period, also planned to increase innovation-oriented funding the production sector to $20 \%$ of GDP on the basis of public support targeted programs, the share of budget funding of basic science to $4 \%$ of GDP. In the period up to 2010 was the goal on the basis of domestic macro-developed high-tech manufacturing industries: aviation, space technology, radio industry, nuclear energy, defense industry.

In the second stage (2012-2016) it is planned diversification of the economics' structure on the basis of structural and investment flexibility for priority development of high-tech industries and innovative technologies for the expansion of social innovation infrastructure through the development and deployment of NIS domestic market of Innovation and Technology (RIT). During this period it is planned to form an investment-stimulating tax system, to develop international co-operation based on the growth of exports of high technology and high-tech products [5, p. 191].

And finally, in the third stage (2016-2025) Provides a transition to the deployment of completed cycles, expanded reproduction through innovative integration of scientific and innovation potential, recovery of highly qualified scientific and human capacity through the introduction of universal higher education [5, p. 194].

Thus, for many decades, the foundation of the Russian economy was based on the extensive guidelines to focus mainly on quantitative rather than qualitative changes. Abundant natural and human resources, and centralized management raised the Russian economy from the ruins of the war. Such economic leap allowed to shorten the technological gap between Russia and developed countries. However, even a change of policy in the 70's and 80 's. did not cause qualitative changes in the economy. Rate has been made on the development of the commodity sector. Although in these years was an attempt to develop small businesses. It should be noted that the majority of this class later went to trade (the so-called «shuttle traders» in the 90's), avoiding the real production sector of the economy. Scientifictechnical sphere of the economy and at all left unnoticed. Private business refused to fund basic research. No funding is not possible to buy modern equipment to replace obsolete and, therefore, there is no scientific research and projects. This caused the exodus of scientists from the country. In science, there are only people «ideological». Young professionals from science abandoned in favor of business as well as the salary of a young scientist could not solve many of the social and domestic problems. So faded scientific and technical potential. Commodity and financial markets were promised an «easy» and «quick» profits (even profit) on investments, which could not guarantee research projects. However, the crisis of 2008-2009 showed that only raw materials and financial sectors cannot provide the stability of the economy and society. At the same time came the final realization of the need of Russia's transition to innovative development and non-resource-based economy.

So what happens now? The Russian economy in 2011, according to Rosstat, grew by $4.3 \%$. At the same time, the Statistical Office restated 2010 results: the same $4.3 \%$ instead of $4 \%$. Thus, the GDP has finally reached pre-crisis levels [8].

Comparison of the two crises have shown that in both cases a lot of stress provoked about the same decline in production of $10 \%$. The similarities end. 
On recovery in 1998 left 21 months, and this time the economy recovers, according to «Renaissance Capital», twice as long [1]

At the same time, 13 years ago changed the model of development, and now it is the same. After 1998, the main driver of growth were investments, and now the Russian economy is strongly dependent on the willingness of people to spend their borrowed money: consumer boom is a key to sustaining growth. Recovery rate of consumption, this time really surprised: consumer demand has returned to good growth much faster than it did the last time.

The low speed of the current recovery is mainly due to sluggish business investment. Data on rates of investment growth after two crises fully reflect the differences in the economic recovery after the 1998 and 2008

Compared with the market during the crisis of 1997-1999, during the crisis of the last episode of the stock market crashed not so much, and restored comparable rates. Based on the RTS index, the market for eight months of the downward trend from June 2008 to January of 2009 - fell by $80 \%$. Whereas in the late 1990s, The value of the cumulative decline from August 1907 to September 1998 was $91 \%$. Pre-crisis levels RTS index reached only in the fall of 2003. Now, in the long-term recovery, the market is far behind the rate of a decade ago. For the first 36 months of recovery the updating RTS index in 1998-2001 increased by 4.1 times, and for the period of the same duration from February 2009 to January 2012 the first - 3 times [4].

From the foregoing, it can be stated: when the possibility of financing domestic economic processes depend on the external environment, foreign creditors and investors - it creates unnecessary risk. After a short interruption due to the crisis, once again began to grow the Russian corporate external debt industrial companies and banks. [7] The situation is complicated by the fact that adequate mechanisms for replacement of external sources inside hardly used.

The main issue center - Central Bank - in the implementation of the issue and the formation of the monetary base since the crisis returned to external sources, when ruble liquidity created by foreign exchange inflows and export earnings by attracting foreign currency loans from abroad. The practice of relying on internal factors in shaping the ruble monetary base, which have become more important in times of crisis, again put on the backburner. As a result of increased dependence of the monetary areas of the Russian economy on the world market, with all the negative consequences. Obviously, in the case of preservation of such trends in the future, not only complicate the decision to diversify and modernize the economy, its departure from the raw materials, but also the status of raw materials exporter in time could be lost due to the depletion of resources. [3]

It is no accident that the Russian authorities in recent years-old are to give preference to domestic capital markets, in every way possible to avoid the growth of foreign loans. In absolute terms, the volume of funds raised through internal bond reached a new record high.

Only in January-February 2012 domestic debt increased by almost 76 billion rubles. Build up of debt is accelerated, and after three years, he more than doubled in nominal terms, or about 2/3 of GDP. [2] The external borrowing to rise almost will not their government still considers a «threat to sovereignty».

As heard reports the Ministry of Finance, the amount of domestic debt securities at March 1, 2012 exceeded 3.6 trillion. rub. If we take into account the state guarantees for raising funds in various projects (last year, for example, guarantees the obligations of defense companies and «Rusnano»), then at the beginning of the year domestic commitments Russia made more than $\$ 4$ trillion. rub.

According to forecasts of the Ministry of Finance of this year the Government may draw from the domestic market 1.8 trillion. rub., and by the end of 2014, total domestic debt can achieve impressive numbers (almost 10 trillion. rub.). Total debt from the current $10 \%$ of GDP will rise to $17 \%$. The main purpose of attracting money from the external market - covering the budget deficit.

The low level of external debt has become a kind of pride for the government, which try to mention at every opportunity. However, the leading rating agency of this one to raise Russia's sovereign rating is still considered inadequate.

The events that occurred in the world in recent years, gave a powerful impetus to the formation of qualitatively different base of the global economic system. Now there are unique (by historical standards), the opportunity to form a qualitatively different approaches and mechanisms that can lay the foundation for sustainable development in Russia for many years ahead, strengthening its international position and turning it into one of the major centers of economic and political influence in the world. But with only one exception.

Due to the unconditional and non-stop the spread of free trade rules and, above all, the free movement of capital and financial account, «the 
economy» is increasingly free from political control, in fact, the basic meaning of the term «economics» was - «non-political area».

One of the most important implications of the new global freedom displacements - something that is becoming increasingly difficult, perhaps even impossible to recast social problems in an effective collective action. Now, the main source of surprise and uncertainty was the behavior of the «markets»in the first place, the world of finance. Accordingly, it is easy to see why replacing territorial «weak states» some legislative and governing bodies of the global nature would cause damage to the interests of the «world market» therefore begs the suspicion that political fragmentation and economic globalization do not collide and do not fight with each other, and, on the contrary, are close allies. Integration and parcellation, globalization and territory rializatsiya is mutually complementary processes. That is due to the coincidence and the interweaving of opposing tendencies, the same pu-ber in the course of the differential impact of the new freedom of movement, so-called «globalizing» processes which lead to a redistribution of privileges and deprivations, resources and impotence, freedom and coercion. Today we are witnessing the world restratifikatsii in which develops a new socio-cultural hierarchy on a worldwide scale. Therefore, it is the new wave of the global crisis will not allow us to relax.

\section{References}

1. After 1998, Russia Reduced Investors, and after 2008 - Consumers / / The Website of IA «Finmarket» [Electronic resource]: URL: http://finmarket.ru/z/nws/hotnews.asp?id=2718427) (date of access: January, 20 2016).

2. Debt - an Internal Affair of Russia / / Website News Agency «Finmarket»[Electronic resource]: URL: http://finmarket.ru/z/nws/hotnews.asp?id=2802689 (date of access: January, 18 2016).

3. Ershov M. Peace in Post-crisis Conditions - New Problems / / Day-gi and credit. 2012. Number 1. P. 53.

4. Indicators. Business Climate / / Ekspert.2012. № 6 (789). P. 94.

5. Novitsky, N.A. Innovative Economy in Russia: Theoretical Foundations and Strategic Priorities. M.: URSS, Knizh. Dom «LIBROKOM», 2009. 328 p.

6. Peshkov, A.A., Matsko, N. Paradoxes of Economic growth Based on the Development of the Mineral Sector [Electronic resource]. / / Problems of the modern economy. 2008. 1 (25). URL: http:// www.meconomy.ru/art.php3 ?artid=23338 (date of access: January, 19 2016).

7. Shapovalov A. Private External Debt back to RUSSIA / / Kommersant. 2011. № 58 (4599). [Electronic resource]: URL: http://www.kommersant.ru/docy/1615109 (date of access: January, 20 2016).

8. The Official Website of the Federal State Statistics Service (date of access: January, 18 2016). 